\title{
Response of Yield and Yield Components of Tef [Eragrostis tef (Zucc.) Trotter] to Tillage, Nutrient, and Weed Management Practices in Dura Area, Northern Ethiopia
}

\author{
Gebreyesus Brhane Tesfahunegn \\ College of Agriculture, Aksum University-Shire Campus, P.O. Box 314, Shire, Ethiopia \\ Correspondence should be addressed to Gebreyesus Brhane Tesfahunegn; gebre33@gmail.com
}

Received 6 March 2014; Revised 16 May 2014; Accepted 19 May 2014; Published 13 July 2014

Academic Editor: Dongmei Zhou

Copyright (C) 2014 Gebreyesus Brhane Tesfahunegn. This is an open access article distributed under the Creative Commons Attribution License, which permits unrestricted use, distribution, and reproduction in any medium, provided the original work is properly cited.

\begin{abstract}
The low average grain yield $\left(0.7\right.$ ton $\left.\mathrm{ha}^{-1}\right)$ of tef in Ethiopia is mainly attributed to low soil fertility, and inappropriate tillage and weeds control practices. Despite this, limited scientific information has been documented so far on their interaction effects on tef crop productivity in northern Ethiopia. The objective of this study was to assess the separate and interaction effects of tillage, fertilizer, and weed control practices on tef yield and yield components in the conditions of northern Ethiopia. A two-year study (2008-2009) was conducted using split-split-plot design with three replications. In the main plot, three tillage treatments: conventional tillage ( 6 times tillage passes) (T1), four times tillage passes (T2), and reduced tillage (single tillage pass at sowing)

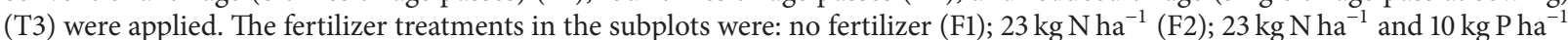
(F3); $23 \mathrm{~kg} \mathrm{Nha}^{-1}$ and 2.5 ton manure ha ${ }^{-1}$ (F4); and 2.5 ton manure ha ${ }^{-1}$ (F5). The sub-subplot weed control treatments included farmer weed control practice or hand weeding (W1); $2,4 \mathrm{D}$ at $0.75 \mathrm{~kg} \mathrm{ha}^{-1}$ at five-leaf stage; $2,4 \mathrm{D}$ at $0.75 \mathrm{~kg} \mathrm{ha}^{-1}$ at six-leaf stage; $2,4 \mathrm{D}$ at $1.5 \mathrm{~kg} \mathrm{ha}^{-1}$ at five-leaf stage; and 2,4D at $1.5 \mathrm{~kg} \mathrm{ha}^{-1}$ at six-leaf stage. This study showed that the separate and interaction effects of tillage, fertilizer, and weed control practices significantly affected tef crop yield and yield components in both crop seasons. T2 increased tef yield by $>42 \%$ over the other tillage and F3 increased yield by $>21 \%$ over the other fertilizer treatments. Grain yield increased by $>23 \%$ due to W1. This study thus suggested that promising treatments such as T2, F3, and W1 should be demonstrated at on-farm fields in order to evaluate their performance at farmers' conditions.
\end{abstract}

\section{Introduction}

Tef [Eragrostis tef (Zucc.) Trotter] is an Ethiopian cultivated crop which is mainly grown for its grain as a major staple food and market cereal crop. Most tef grains are made into injera (most popular food in the national diet), which is flat spongy and slightly sour bread that looks like a giant bubbly pancake [1]. The annual area covered by tef during the main season is about 1.91 million ha, that is, accounted for $29 \%$ of the total cereal area in Ethiopia which stands first in its area coverage [2]. Despite the fact that tef has widely grown under a wide range of altitudes (300 to $2800 \mathrm{~m}$ above sea level), climate conditions, and soil types $[1,3]$, the average grain yield in Ethiopia is about 0.7 ton ha ${ }^{-1}$ [3]. A lower tef yield than this could be found in the dry parts of the country [3].

Lower tef grain yield is mainly attributed to low soil fertility, especially, nitrogen $(\mathrm{N})$ and phosphorus $(\mathrm{P})$ deficiencies [4] and inappropriate tillage and weed control practices $[3,5]$. Other studies also added that weed is one of the key limiting factors for attaining higher tef yield [6]. Despite this fact, limited research information has documented so far the interaction effects of tillage practices and organic and inorganic fertilizers integrated with weed management 
practices on yield and yield component of tef crop in northern Ethiopia.

Low soil fertility is exacerbated by soil fertility depletion through nutrient removal with harvest, tillage, weeding, and losses in runoff and soil erosion [7, 8]. Many farmers are unable to compensate for such losses, which resulted in negative nutrient balances [9]. This situation is worsened by low input continuous cultivation and overgrazing [7]. Researchers suggested that nutrient availability can be improved by nutrient application such as inorganic or organic fertilizer or their combination (e.g., [10]). Despite the great efforts on $\mathrm{N}$ and $\mathrm{P}$ sources fertilizers application to improve the yield of tef by farmers, the nonaffordable cost of inorganic fertilizer and high risk in the semiarid areas challenge adopting fertilizer technology by farmers.

Substantial studies have shown that intensive cultivation generally increases the potential for soil erosion due to the breakdown of soil aggregates and reduction of soil cohesion and thus decreases soil nutrient (e.g., [11, 12]). Generally, farmers practice with conventional tillage is aimed to control weeds, conserve moisture, and increase soil warming [5]. But the consequence of such repeated operations causes moist soil to move to the surface which favors loss of water by evaporation, exposing soil to erosion damage [5]. Many other studies have also noted that when a similar tillage system has been practiced for a long period, the practice can alter soil properties and agricultural production [13-17]. Conventional tillage is reported as a factor that aggravates crop yield reduction $[3,18,19]$, but it is still continuing as sole cultivation method in northern Ethiopia. In contrast to this, other studies have reported a significant increase in crop productivity using reduced tillage $[20,21]$. Such increment could be a result of its long-term effect on an overall hydrological behaviour of soils $[13,17,20]$. Other researchers (e.g., [22-24]) noted that it is essential to select a tillage practice that sustains and favors successful growth of agricultural crops in a given environmental condition.

The capacity of tef to compete with weeds, which is one of the main yield limiting biotic factors, is poor. As a result, hand weeding as the main method of weed control has been practiced for many years even though labor shortage as a constraint is being increased. In view of such shortcoming, herbicides (e.g., 2,4D and MCPA) have been applied on tef even though the rate and time of application varied across the smallholder farmers [25]. It is clearly indicated in the previous studies that emphasis should be given to both rate and time of application of herbicides on tef crop $[25,26]$. This is because the response of cereals such as tef to the herbicides varies with growth (leaf) stages as herbicides can cause leaf deformity and sterility at certain stages [25-27], indicating that identification of the safest time of application (most tolerance growth stage) is crucial.

Even though variability in tillage types and intensity, fertilizer rates and types, and weed control practices can affect crop production, limited scientific information is documented with regard to their short-term effects on tef crop production in a Cambisols in northern Ethiopia. However, it is a prerequisite to quantify such effects on crop production while designing site-specific applications such as fertilizer

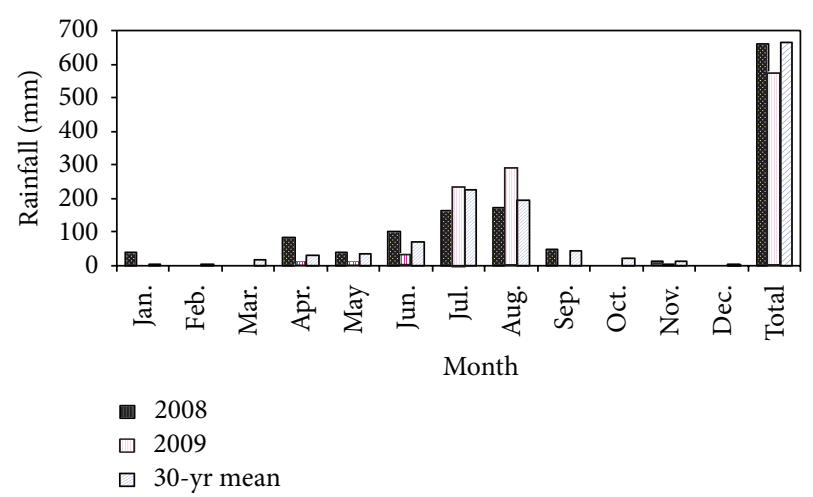

FIGURE 1: Monthly and total annual rainfall for 2008, 2009, and 30year average (source: Meteorological agency, Mekelle branch).

rates, proper tillage frequency, and weed management practices [11]. This study was aimed to assess tef yield and yield components response to separation and interaction effects of tillage, fertilizer, and weed control practices.

\section{Materials and Methods}

2.1. Study Area Description. The experiment was conducted under rain-fed conditions from 2008 to 2009 (two years) at Dura Farmers Training Center, an administrative unit of Tigray region of northern Ethiopia. The location of the study site is latitude: $14^{\circ} 07^{\prime} \mathrm{N}$, longitude: $38^{\circ} 44^{\prime} \mathrm{E}$, and altitude: $2050 \mathrm{~m}$ a. s. 1. The slope of the experimental site was about $2 \%$. The site is one of the most tef growing areas in the Tigray region but productivity has hampered by different factors. It has a unimodal rainfall with the main rainy season from July to early September. More than $68 \%$ of the annual rainfall was recorded in July and August. The average annual rainfall and temperature of the area are $700 \mathrm{~mm}$ and $20^{\circ} \mathrm{C}$, respectively.

The rainfall during planting time (July 2008) was lower as compared to the 30-year average. However, the rainfall during July 2009 (planting time) and the 30-year average was almost the same in amount (Figure 1). A higher rainfall in August 2009 as compared to August 2008 and the 30-year average was observed. Despite this, during the grain filling stage of most crops (September 2009), rainfall was little to none. The reverse was observed in September 2008 and for the 30-year average (Figure 1). This figure also showed a similar trend in total annual rainfall in 2008 and the 30 -year average.

The soil texture of the experimental site (49\% sand, $25 \%$ silt, and $26 \%$ clay) was sandy clay loam and the soil type is classified as Chromic Cambisols according to FAO/UNESCO [28]. The soil showed neutral $\mathrm{pH}$ (7.07), very low organic carbon $(0.76 \%)$, low total nitrogen $(0.05)$, and medium available phosphorus $\left(8.6 \mathrm{mg} \mathrm{kg}^{-1}\right)$. The soil sampling and analysis procedure for these parameters is given briefly in Section 2.3.

2.2. Experimental Design, Treatments, and Procedure. The experiment was conducted in 2008 and 2009 crop seasons 
in which treatments were applied to the same experimental units each year using split-split-plot design with three replications. In the main plot, three tillage treatments in a randomized complete block design (RCBD) were applied. These tillage treatments were conventional tillage (6 times tillage passes) (T1), four times tillage passes (T2), and reduced tillage (single tillage pass at sowing) (T3). The treatments were practiced according to the traditional plowing system of oxen-drawn plow using local implement which is known as maresha. The only difference in the treatments was the number of tillage passes.

The fertilizer treatments in the subplots were no fertilizer (F1); $23 \mathrm{~kg} \mathrm{Nha}^{-1}$ (F2); $23 \mathrm{~kg} \mathrm{Nha}^{-1}$ and $10 \mathrm{~kg} \mathrm{Pha}^{-1}$ (F3); $23 \mathrm{~kg} \mathrm{Nha}^{-1}$ and 2.5 ton manure $\mathrm{ha}^{-1}$ (F4); and 2.5 ton manure ha ${ }^{-1}$ (F5). The source of nitrogen (N) was urea and that of phosphorous $(\mathrm{P})$ was diammonium phosphate (DAP). DAP was applied at planting time whereas urea was applied at 4 weeks after planting. Manure was applied just at planting time and mixed with the soil using oxen-plowing. Manure was collected and stored in a pit for 3 months before the application time. The source of manure was cattle which fed indoor commonly on hay and crop residue (mainly tef straw) with silage. The literature shows that 2.5 ton manure can produce about $46 \mathrm{~kg} \mathrm{~N}$ but half $(50 \%)$ of this $\mathrm{N}$ was assumed to be exposed to different losses during collection, storage, and application (e.g., Hati et al. [29]).

The sub-subplot weed control treatments were farmer weed control practice (hand weeding) (W1); 2,4D at $0.75 \mathrm{~kg} \mathrm{ha}^{-1}$ at five-leaf stage (W2); $2,4 \mathrm{D}$ at $0.75 \mathrm{~kg} \mathrm{ha}^{-1}$ at sixleaf stage (W3); $2,4 \mathrm{D}$ at $1.5 \mathrm{~kg} \mathrm{ha}^{-1}$ at five-leaf stage (W4); and $2,4 \mathrm{D}$ at $1.5 \mathrm{kgha}^{-1}$ at six-leaf stage (W5). 2,4D was applied for in season broad leaf control. The tef variety DZ/01/974 seeds were broadcasted uniformly by hand at a rate of $30 \mathrm{~kg} \mathrm{ha}^{-1}$ after plots were compacted by trampling with human labor. All sub-subplots with W1 were weeded manually twice and the remaining weeded one time for narrow leaf weeds only during the cropping season. Dates of all management practices such as planting, weeding, tillage, harvesting, fertilizer, and herbicide application time were recorded (Table 1 ). The size of the main plot, subplot, and sub-subplot was $19 \mathrm{~m} \times 19 \mathrm{~m}, 3 \mathrm{~m} \times 19 \mathrm{~m}$, and $3 \mathrm{~m} \times 3 \mathrm{~m}$, respectively. The spacing between main plots, subplots, and sub-subplots was $1.5,1.0$, and $0.5 \mathrm{~m}$, respectively.

2.3. Soil Sampling and Analysis. Five composite disturbed soil samples were collected randomly at the $0-20 \mathrm{~cm}$ soil depth from the entire experimental site before imposing any treatment at the beginning of the research period in 2008. The disturbed soil samples were pooled and mixed thoroughly in a basket and a subsample of $500 \mathrm{~g}$ was taken for analysis. The subsamples were air-dried, passed through $2 \mathrm{~mm}$ sieve, and analyzed for selected soil parameters (soil texture, $\mathrm{pH}$, organic carbon, total nitrogen, and available phosphorous) using standard laboratory procedures. Results of soil parameters are described on Section 2.1.

2.4. Data Collection and Analysis. Plant height of the tef crop was measured from the surface ground to the tip of the
TABLE 1: Agronomic activities of tef crop versus their time of application during the experiment period.

\begin{tabular}{|c|c|c|}
\hline \multirow{2}{*}{ Activities } & \multicolumn{2}{|c|}{ Year } \\
\hline & 2008 & 2009 \\
\hline 1st tillage & 05 April 2008 & 04 April 2009 \\
\hline 2nd tillage & 04 May 2008 & 03 May 2009 \\
\hline 3rd tillage & 02 June 2008 & 03 June 2009 \\
\hline 4th tillage & 21 June 2008 & 20 June 2009 \\
\hline 5th tillage & 02 July 2008 & 01 July 2009 \\
\hline Planting time $\mathrm{e}^{\mathrm{a}}$ & 16 July 2008 & 15 July 2009 \\
\hline 1st hand weeding & 14 August 2008 & 13 August 2009 \\
\hline $2,4 \mathrm{D}$ application time & 15 August 2008 & 14 August 2009 \\
\hline Urea application time & 16 August 2008 & 15 August 2009 \\
\hline Tillering time & 22 August 2008 & 22 August 2009 \\
\hline 2nd hand weeding & 02 September 2008 & 02 September 2009 \\
\hline Stem elongation time & 8 September 2008 & 7 September 2009 \\
\hline Booting stage & 21 September 2008 & 21 September 2008 \\
\hline Grain filling time & 15 Oct 2008 & 15 Oct 2009 \\
\hline Harvesting time & 15 November 2008 & 16 November 2009 \\
\hline
\end{tabular}

${ }^{\mathrm{a}}$ The 6 th tillage pass for T1, 4th tillage pass for T2, and the 1st tillage pass for $\mathrm{T} 3$ were applied just during the planting time.

panicle at maturity time from representative 10 plants (short, medium, and tall). Tillering of the crop that considered the number of additional plants growing from the main stem of tef at each sub-subplot was counted from 10 plants. Tef plants in a $1 \mathrm{~m}^{2}$ quadrant were harvested for recording above ground biomass and grain yield at full maturity stage from each subsubplot. A sample of $50 \mathrm{gm}$ seeds of tef was weighed and then air-dried and finally adjusted to constant moisture level of $12 \%$. Harvest index was calculated by the ratio of grain yield to above ground biomass. Data were subjected to analyses of variance using Statistix V9 (Analytical Software, Tallahassee, FL). When treatment effects were significant, least significant difference (LSD) mean separation at probability level $(P)=$ 0.05 was applied.

\section{Results and Discussion}

3.1. Effects of Tillage, Fertilizer, and Weed Control Practices on Tef Yield and Yield Components in 2008 Crop Season. The separate and interaction effects of tillage, fertilizer, and weed control practices significantly $(P \leq 0.05)$ affected most yield and yield components of tef crop (Table 2). For instance, tiller number was significantly varied between T2 and $\mathrm{T} 3$ and $\mathrm{T} 1$ and $\mathrm{T} 2$. But tiller number was nonsignificantly differed between $\mathrm{T} 1$ and $\mathrm{T} 3(P>0.05)$, indicating that both treatments did show similar effect on soil moisture and thereby on plant tillering. The highest mean tiller number was observed from T2 (5.6) and the lowest was from T3 (4.3). Tillering was also significantly influenced by fertilizer rate and weed control practices. The unfertilized (F1) plot showed a significantly lower tillering number as compared to the others. However, there were nonsignificant differences in tiller number among the remaining plots which received 
TABLE 2: Separate and interaction effects of tillage, fertilizer, and weed control treatments on yield and yield components of tef crop in 2008 crop season.

\begin{tabular}{|c|c|c|c|c|c|c|}
\hline Treatment & $\mathrm{TL}$ & $\mathrm{PH}(\mathrm{cm})$ & $\mathrm{PL}(\mathrm{cm})$ & GY $\left(\mathrm{tha}^{-1}\right)$ & $\operatorname{AGB}\left(\mathrm{tha}^{-1}\right)$ & $\mathrm{HI}$ \\
\hline \multicolumn{7}{|l|}{ Tillage (T) } \\
\hline Conventional tillage $(6$ times passes $)=\mathrm{T} 1$ & $4.5^{\mathrm{b}}$ & $84^{\mathrm{b}}$ & $15^{\mathrm{b}}$ & $1.2^{\mathrm{b}}$ & $5.0^{\mathrm{b}}$ & $0.24^{\mathrm{b}}$ \\
\hline Four times tillage passes $=\mathrm{T} 2$ & $5.6^{\mathrm{a}}$ & $98^{\mathrm{a}}$ & $19^{\mathrm{a}}$ & $1.6^{\mathrm{a}}$ & $5.7^{\mathrm{a}}$ & $0.28^{\mathrm{a}}$ \\
\hline Reduced tillage (single tillage pass) $=\mathrm{T} 3$ & $4.3^{\mathrm{b}}$ & $72^{\mathrm{c}}$ & $14^{\mathrm{b}}$ & $1.0^{\mathrm{b}}$ & $4.8^{\mathrm{b}}$ & $0.21^{\mathrm{c}}$ \\
\hline \multicolumn{7}{|l|}{ Fertilizer $(\mathrm{F})$} \\
\hline No fertilizer $=\mathrm{F} 1$ & $4.5^{\mathrm{b}}$ & $68^{\mathrm{c}}$ & $14^{\mathrm{c}}$ & $0.82^{\mathrm{d}}$ & $4.0^{\mathrm{d}}$ & $0.21^{\mathrm{a}}$ \\
\hline $23 \mathrm{~kg} \mathrm{Nha}^{-1}=\mathrm{F} 2$ & $6.3^{\mathrm{a}}$ & $85^{\mathrm{b}}$ & $18^{\mathrm{b}}$ & $1.1^{\mathrm{bc}}$ & $6.2^{\mathrm{b}}$ & $0.18^{\mathrm{b}}$ \\
\hline $23 \mathrm{~kg} \mathrm{Nha}^{-1}$ and $10 \mathrm{~kg} \mathrm{Pha}^{-1}=\mathrm{F} 3$ & $6.7^{\mathrm{a}}$ & $102^{\mathrm{a}}$ & $21^{\mathrm{a}}$ & $1.7^{\mathrm{a}}$ & $7.2^{\mathrm{a}}$ & $0.24^{\mathrm{a}}$ \\
\hline $23 \mathrm{~kg} \mathrm{Nha}^{-1}$ and $2.5 \mathrm{tha}^{-1}$ manure $=\mathrm{F} 4$ & $6.5^{\mathrm{a}}$ & $88^{\mathrm{b}}$ & $19^{\mathrm{b}}$ & $1.3^{\mathrm{b}}$ & $6.3^{\mathrm{b}}$ & $0.21^{\mathrm{a}}$ \\
\hline $2.5 \mathrm{tha}^{-1}$ manure $=\mathrm{F} 5$ & $6.2^{\mathrm{a}}$ & $87^{\mathrm{b}}$ & $18^{\mathrm{b}}$ & $1.0^{\mathrm{c}}$ & $5.9^{\mathrm{c}}$ & $0.17^{\mathrm{b}}$ \\
\hline \multicolumn{7}{|l|}{ Weed control practices $(\mathrm{W})$} \\
\hline Hand weeding $=\mathrm{W} 1$ & $6.5^{\mathrm{a}}$ & $93^{\mathrm{a}}$ & $20^{\mathrm{a}}$ & $1.6^{\mathrm{a}}$ & $5.4^{\mathrm{a}}$ & $0.30^{\mathrm{a}}$ \\
\hline $2,4 \mathrm{D}$ at $0.75 \mathrm{~kg} \mathrm{ha}^{-1}$ at five-leaf stage $=\mathrm{W} 2$ & $6.0^{\mathrm{a}}$ & $88^{\mathrm{b}}$ & $18^{\mathrm{b}}$ & $1.3^{\mathrm{b}}$ & $4.5^{\mathrm{b}}$ & $0.29^{\mathrm{ab}}$ \\
\hline $2,4 \mathrm{D}$ at $0.75 \mathrm{~kg} \mathrm{ha}^{-1}$ at six-leaf stage $=\mathrm{W} 3$ & $5.3^{\mathrm{b}}$ & $85^{\mathrm{b}}$ & $15^{\mathrm{c}}$ & $1.0^{\mathrm{c}}$ & $4.0^{\mathrm{c}}$ & $0.25^{\mathrm{c}}$ \\
\hline $2,4 \mathrm{D}$ at $150 \mathrm{~kg} \mathrm{ha}^{-1}$ at five-leaf stage $=\mathrm{W} 4$ & $5.5^{\mathrm{b}}$ & $86^{\mathrm{b}}$ & $15^{\mathrm{c}}$ & $1.1^{\mathrm{c}}$ & $4.1^{\mathrm{c}}$ & $0.27^{\mathrm{bc}}$ \\
\hline $2,4 \mathrm{D}$ at $150 \mathrm{~kg} \mathrm{ha}^{-1}$ at six-leaf stage $=\mathrm{W} 5$ & $4.7^{\mathrm{c}}$ & $81^{\mathrm{c}}$ & $13^{\mathrm{d}}$ & $0.98^{c}$ & $3.7^{\mathrm{d}}$ & $0.26^{\mathrm{c}}$ \\
\hline \multicolumn{7}{|l|}{ Interaction } \\
\hline $\mathrm{T} \times \mathrm{F}$ & $*$ & $*$ & $* *$ & $* *$ & $* *$ & * \\
\hline $\mathrm{T} \times \mathrm{W}$ & $*$ & $*$ & $*$ & $*$ & * & $*$ \\
\hline $\mathrm{F} \times \mathrm{W}$ & $*$ & * & ns & $*$ & $*$ & ns \\
\hline $\mathrm{T} \times \mathrm{F} \times \mathrm{W}$ & $*$ & $* *$ & $* *$ & $* *$ & $* *$ & $*$ \\
\hline
\end{tabular}

Means within columns with different letters are significantly different at $P \leq 0.05$.

${ }^{*}$ Significant at the 0.05 probability level; ${ }^{*}{ }^{*}$ significant at the 0.01 probability level; ns: nonsignificant at $P>0.05$.

$\times$ indicates interaction; TL: tiller number per plant; PH: plant height; PL: panicle length; GY, grain yield; AGB: above ground biomass yield; HI: harvest index $(-)$.

different fertilizer rates. In general, the effect of fertilizer showed a higher tiller number as compared to the tillage and weed control treatment effects.

A significant difference in tef plant height among the tillage, fertilizer, and weed control treatments was observed (Table 2). The tallest plant height was recorded as a result of F3 $(102 \mathrm{~cm})$ followed by T2 $(98 \mathrm{~cm})$ and $\mathrm{W} 1(93 \mathrm{~cm})$. The lowest plant height was measured from F1 $(68 \mathrm{~cm})$. Plant height influences above ground biomass yield of a crop. Similarly, panicle length and aboveground biomass yield were significantly affected by the separate effects of the treatments (Table 2). The largest tef above ground biomass yield was measured from F3 $\left(7.2 \mathrm{tha}^{-1}\right)$ followed by F4 $\left(6.3 \mathrm{tha}^{-1}\right)$ whereas the lowest was observed from F1 $\left(4.0 \mathrm{tha}^{-1}\right)$. This trend was similar with grain yield in which the highest grain yield was measured from F3 $\left(1.7 \mathrm{t} \mathrm{ha}^{-1}\right)$ and the lowest was from F1 $\left(0.82 \mathrm{tha}^{-1}\right)$. The highest HI was found from W1 (0.30). Even though the manure in F4 contains more nutrients, their availability (releasing) to the crop in a season is too slow. In addition, as soil nutrients increase more soil water is demanded by the crop in which water is a critical constraint in the study area conditions. This could be the reason for F4 not having the highest yield as compared to F3. The interaction effects of $\mathrm{T} \times \mathrm{F}, \mathrm{T} \times \mathrm{W}, \mathrm{F} \times \mathrm{W}$, and $\mathrm{T} \times \mathrm{F} \times \mathrm{W}$ significantly influenced tillering, plant height, panicle length, biomass yield, grain yield, and HI of the tef crop variety tested in this experiment (Table 2). But the influence of the 3-way ( $\mathrm{T}$ $\times \mathrm{F} \times \mathrm{W}$ ) interaction on yield and yield components of tef was found much better than the 2-way interaction.

\subsection{Effects of Tillage, Fertilizer, and Weed Control Practices} on Tef Yield and Yield Components in 2009 Crop Season. The measured agronomic variables of tef crop in 2009 crop season showed significant differences for the separate and interaction effects of tillage, fertilizer, and weed control treatments (Table 3). Tillering was significantly influenced by the separate and interaction effects of these treatments. The effect of fertilizer followed by weed control practices showed a higher tiller number. The fertilizer rates that showed the highest tiller number were F3 (6.9) and F4 (6.8). This was followed by the weed control treatment of W1 (6.7). Among the tillage practices, T2 showed the highest tiller number (6.2). The lowest tiller number was measured from F1. The tallest plant height was measured from F4 $(105 \mathrm{~cm})$ followed by F3 $(104 \mathrm{~cm})$ and T2 $(102 \mathrm{~cm})$. From the weed control treatments, W1 resulted in the highest tef plant height. The highest panicle length was recorded from the main plot effect of T2 $(24 \mathrm{~cm})$ followed by the fertilizer rate of F3 $(23 \mathrm{~cm})$. This indicated that panicle length also affected by synergetic effects of tillage practices and soil nutrient additions from fertilizer.

Tillage, fertilizer, and weed control treatments significantly affected aboveground biomass yield of tef crop. A 
TABLE 3: Main and interaction effects of tillage, fertilizer, and weed control practices on yield and yield components of tef crop in 2009 crop season.

\begin{tabular}{|c|c|c|c|c|c|c|}
\hline Treatment & $\mathrm{TL}$ & $\mathrm{PH}(\mathrm{cm})$ & $\mathrm{PL}(\mathrm{cm})$ & GY $\left(\mathrm{tha}^{-1}\right)$ & $\operatorname{AGB}\left(\mathrm{tha}^{-1}\right)$ & HI \\
\hline \multicolumn{7}{|l|}{ Tillage (T) } \\
\hline Conventional tillage $(6$ times passes $)=\mathrm{T} 1$ & $4.2^{\mathrm{c}}$ & $81^{\mathrm{c}}$ & $13^{\mathrm{c}}$ & $1.1^{\mathrm{c}}$ & $4.8^{\mathrm{c}}$ & $0.23^{\mathrm{b}}$ \\
\hline Four times tillage passes $=\mathrm{T} 2$ & $6.2^{\mathrm{a}}$ & $101^{\mathrm{a}}$ & $24^{\mathrm{a}}$ & $1.7^{\mathrm{a}}$ & $6.2^{\mathrm{a}}$ & $0.27^{\mathrm{a}}$ \\
\hline Reduced tillage (single tillage pass) $=\mathrm{T} 3$ & $5.0^{\mathrm{b}}$ & $94^{\mathrm{b}}$ & $17^{\mathrm{b}}$ & $1.4^{\mathrm{b}}$ & $5.8^{\mathrm{b}}$ & $0.24^{\mathrm{b}}$ \\
\hline \multicolumn{7}{|l|}{ Fertilizer $(\mathrm{F})$} \\
\hline No fertilizer $=\mathrm{F} 1$ & $4.0^{\mathrm{d}}$ & $63^{\mathrm{d}}$ & $12^{\mathrm{c}}$ & $0.79^{\mathrm{d}}$ & $3.7^{\mathrm{d}}$ & $0.21^{\mathrm{bc}}$ \\
\hline $23 \mathrm{~kg} \mathrm{Nha}^{-1}=\mathrm{F} 2$ & $6.5^{\mathrm{b}}$ & $88^{\mathrm{c}}$ & $19^{\mathrm{b}}$ & $1.1^{\mathrm{c}}$ & $6.0^{\mathrm{c}}$ & $0.18^{\mathrm{d}}$ \\
\hline $23 \mathrm{~kg} \mathrm{Nha}^{-1}$ and $10 \mathrm{~kg} \mathrm{Pha}^{-1}=\mathrm{F} 3$ & $6.9^{\mathrm{a}}$ & $104^{\mathrm{a}}$ & $23^{\mathrm{a}}$ & $1.7^{\mathrm{a}}$ & $7.5^{\mathrm{a}}$ & $0.23^{\mathrm{a}}$ \\
\hline $23 \mathrm{~kg} \mathrm{Nha}^{-1}$ and $2.5 \mathrm{tha}^{-1}$ manure $=\mathrm{F} 4$ & $6.8^{\mathrm{a}}$ & $105^{\mathrm{a}}$ & $22^{\mathrm{a}}$ & $1.5^{\mathrm{b}}$ & $6.8^{\mathrm{b}}$ & $0.22^{\mathrm{ab}}$ \\
\hline $2.5 \mathrm{tha}^{-1}$ manure $=\mathrm{F} 5$ & $6.6^{\mathrm{b}}$ & $98^{\mathrm{b}}$ & $20^{\mathrm{b}}$ & $1.2^{\mathrm{c}}$ & $6.1^{\mathrm{c}}$ & $0.20^{\mathrm{c}}$ \\
\hline \multicolumn{7}{|l|}{ Weed control practices $(\mathrm{W})$} \\
\hline Hand weeding $=\mathrm{W} 1$ & $6.7^{\mathrm{a}}$ & $95^{\mathrm{a}}$ & $21^{\mathrm{a}}$ & $1.7^{\mathrm{a}}$ & $5.6^{\mathrm{a}}$ & $0.30^{\mathrm{a}}$ \\
\hline $2,4 \mathrm{D}$ at $0.75 \mathrm{~kg} \mathrm{ha}^{-1}$ at five-leaf stage $=\mathrm{W} 2$ & $6.2^{\mathrm{b}}$ & $86^{\mathrm{b}}$ & $17^{\mathrm{b}}$ & $1.2^{\mathrm{b}}$ & $4.3^{\mathrm{b}}$ & $0.28^{\mathrm{b}}$ \\
\hline $2,4 \mathrm{D}$ at $0.75 \mathrm{~kg} \mathrm{ha}^{-1}$ at six-leaf stage $=\mathrm{W} 3$ & $5.3^{\mathrm{c}}$ & $78^{\mathrm{d}}$ & $14^{\mathrm{c}}$ & $0.98^{\mathrm{c}}$ & $3.9^{\mathrm{c}}$ & $0.25^{\mathrm{c}}$ \\
\hline $2,4 \mathrm{D}$ at $150 \mathrm{~kg} \mathrm{ha}^{-1}$ at five-leaf stage $=\mathrm{W} 4$ & $5.1^{\mathrm{c}}$ & $82^{c}$ & $13^{\mathrm{c}}$ & $1.0^{\mathrm{c}}$ & $3.7^{\mathrm{c}}$ & $0.27^{\mathrm{b}}$ \\
\hline $2,4 \mathrm{D}$ at $150 \mathrm{~kg} \mathrm{ha}^{-1}$ at six-leaf stage $=\mathrm{W} 5$ & $4.5^{\mathrm{d}}$ & $75^{\mathrm{e}}$ & $11^{\mathrm{d}}$ & $0.96^{\mathrm{c}}$ & $3.5^{\mathrm{d}}$ & $0.27^{\mathrm{b}}$ \\
\hline \multicolumn{7}{|l|}{ Interaction } \\
\hline $\mathrm{T} \times \mathrm{F}$ & * & $*$ & $* *$ & $* *$ & $* *$ & $*$ \\
\hline $\mathrm{T} \times \mathrm{W}$ & $*$ & $*$ & $*$ & * & $*$ & $*$ \\
\hline $\mathrm{F} \times \mathrm{W}$ & * & * & ns & $* *$ & * & ns \\
\hline $\mathrm{T} \times \mathrm{F} \times \mathrm{W}$ & $* *$ & $* *$ & $* *$ & $* *$ & $* *$ & $*$ \\
\hline
\end{tabular}

Means within columns with different letters are significantly different at $P=0.05$.

${ }^{*}$ Significant at the 0.05 probability level; ${ }^{* *}$ significant at the 0.01 probability level; ns: nonsignificant at $P>0.05$.

$\times$ indicates interaction; TL: tiller number per plant; PH: plant height; PL: panicle length; GY: grain yield; AGB: above ground biomass yield; HI: harvest index.

higher aboveground biomass yield of tef was found from T2. However, the effect of the fertilizer rates of F3 and F4 showed the highest biomass yield. The lowest biomass yield was measured from F1 treatment. Generally, this study showed that the response of aboveground biomass yield to the effects of weed control practices is lower than the separate effects of the other factors (Table 3). Tef grain yield was significantly higher in T2 as compared to the other tillage treatments which could be attributed to its contribution in improving soil moisture and nutrient availability. The effects of F3 and F4 on grain yield were significantly higher than the other fertilizer rates. Generally, the effect of fertilizer on grain yield showed was higher than that of weed control treatments. Despite this, the highest HI was found from the weed control treatment of W1 (0.30) which could be attributed to its effect in producing relatively balanced proportion of biomass and grain yield weight. Overall, HI values were very low. The interaction effects of $\mathrm{T} \times \mathrm{F}, \mathrm{T} \times \mathrm{W}, \mathrm{F} \times \mathrm{W}$, and $\mathrm{T} \times \mathrm{F} \times \mathrm{W}$ significantly $(P \leq 0.05)$ influenced yield and yield components of tef crop in 2009 crop season even though the 3-way $(\mathrm{T} \times \mathrm{F} \times \mathrm{W})$ interaction effects on yield and yield components of tef were found much better than the 2-way interaction (Table 3).

3.3. Pooled Analysis Results of Treatment Effects (2008-2009). The two-year pooled data analysis showed that tiller number, plant height, aboveground biomass yield, grain yield, and harvest index were significantly influenced by the separate and interaction treatment effects (Table 4). A higher mean tiller number was found for T2 (5.9) and lower for T1 (4.4). The highest tiller number was measured from F3 (6.8) followed by F4 (6.7). Mean tiller number as a result of W1 was 6.6, which was significantly higher than the other weed control practices. The data of tef plant height showed significantly higher due to $\mathrm{T} 2$ as compared to the other tillage treatments. The tallest plant height of tef crop was measured from F3 $(103 \mathrm{~cm})$ and the shortest was from F1 $(66 \mathrm{~cm})$. Among the weed control practices, W1 showed a significantly higher plant height.

The pooled analysis result on aboveground biomass yield showed a similar trend to that of plant height and tillering. Treatment T2 $\left(6.0 \mathrm{tha}^{-1}\right)$ showed a higher biomass yield as compared to that of T1 $\left(4.9 \mathrm{tha}^{-1}\right)$ and T3 $\left(5.3 \mathrm{tha}^{-1}\right)$. The treatment F3 $\left(7.4 \mathrm{tha}^{-1}\right)$ showed the highest mean biomass yield as compared to the tillage and weed control treatments. The lowest mean biomass yield was found from W5 $\left(3.6 \mathrm{tha}^{-1}\right)$ followed by W4 and F1 $\left(3.9 \mathrm{tha}^{-1}\right)$ which could be most probably due to chemical effects on the crop growth and lack of soil nutrients such as $\mathrm{N}$ and $\mathrm{P}$ and soil moisture. Nitrogen $(\mathrm{N})$ might not be mineralized at enough level from soil organic matter to meet much of the $\mathrm{N}$ needed for the crop unless applied as fertilizer in the study area condition. This study also demonstrated that pooled tef grain yield was significantly higher for T2 than T1 and T3. This may be due to poor infiltration rate of the soils treated by $\mathrm{T} 1$ and 
TABLE 4: Pooled data analysis (2008-2009) results of the separate and interaction effects of the treatments on yield and yield components of tef crop.

\begin{tabular}{|c|c|c|c|c|c|c|}
\hline Treatment & $\mathrm{TL}$ & $\mathrm{PH}(\mathrm{cm})$ & $\mathrm{PL}(\mathrm{cm})$ & GY $\left(\mathrm{tha}^{-1}\right)$ & $\operatorname{AGB}\left(\mathrm{tha}^{-1}\right)$ & HI $(\%)$ \\
\hline \multicolumn{7}{|l|}{ Tillage (T) } \\
\hline Conventional tillage $(6$ times $)$ passes $=\mathrm{T} 1$ & $4.4^{\mathrm{c}}$ & $83^{\mathrm{b}}$ & $14^{\mathrm{b}}$ & $1.2^{\mathrm{b}}$ & $4.9^{\mathrm{c}}$ & $0.24^{\mathrm{b}}$ \\
\hline Four times tillage passes $=\mathrm{T} 2$ & $5.9^{\mathrm{a}}$ & $100^{\mathrm{a}}$ & $22^{\mathrm{a}}$ & $1.7^{\mathrm{a}}$ & $6.0^{\mathrm{a}}$ & $0.28^{\mathrm{a}}$ \\
\hline Reduced tillage (single tillage pass) $=\mathrm{T} 3$ & $4.7^{\mathrm{b}}$ & $83^{\mathrm{b}}$ & $16^{\mathrm{b}}$ & $1.2^{\mathrm{b}}$ & $5.3^{\mathrm{b}}$ & $0.23^{\mathrm{b}}$ \\
\hline \multicolumn{7}{|l|}{ Fertilizer $(\mathrm{F})$} \\
\hline No fertilizer $=\mathrm{F} 1$ & $4.3^{\mathrm{c}}$ & $66^{\mathrm{e}}$ & $13^{\mathrm{c}}$ & $0.81^{\mathrm{d}}$ & $3.9^{\mathrm{d}}$ & $0.21^{\mathrm{b}}$ \\
\hline $23 \mathrm{~kg} \mathrm{Nha}^{-1}=\mathrm{F} 2$ & $6.4^{\mathrm{b}}$ & $87^{\mathrm{d}}$ & $19^{\mathrm{b}}$ & $1.1^{\mathrm{c}}$ & $6.1^{\mathrm{c}}$ & $0.18^{\mathrm{c}}$ \\
\hline $23 \mathrm{~kg} \mathrm{Nha}^{-1}$ and $10 \mathrm{~kg} \mathrm{Pha}^{-1}=\mathrm{F} 3$ & $6.8^{\mathrm{a}}$ & $103^{\mathrm{a}}$ & $22^{\mathrm{a}}$ & $1.7^{\mathrm{a}}$ & $7.4^{\mathrm{a}}$ & $0.23^{\mathrm{a}}$ \\
\hline $23 \mathrm{~kg} \mathrm{Nha}^{-1}$ and $2.5 \mathrm{tha}^{-1}$ manure $=\mathrm{F} 4$ & $6.7^{\mathrm{a}}$ & $97^{\mathrm{b}}$ & $21^{\mathrm{a}}$ & $1.4^{\mathrm{b}}$ & $6.6^{\mathrm{b}}$ & $0.21^{\mathrm{b}}$ \\
\hline $2.5 \mathrm{tha}^{-1}$ manure $=\mathrm{F} 5$ & $6.4^{\mathrm{b}}$ & $93^{\mathrm{b}}$ & $19^{\mathrm{b}}$ & $1.1^{\mathrm{c}}$ & $6.0^{\mathrm{c}}$ & $0.18^{\mathrm{c}}$ \\
\hline \multicolumn{7}{|l|}{ Weed control practices $(\mathrm{W})$} \\
\hline Hand weeding $=\mathrm{W} 1$ & $6.6^{\mathrm{a}}$ & $94^{\mathrm{a}}$ & $21^{\mathrm{a}}$ & $1.6^{\mathrm{a}}$ & $5.5^{\mathrm{a}}$ & $0.31^{\mathrm{a}}$ \\
\hline $2,4 \mathrm{D}$ at $0.75 \mathrm{~kg} \mathrm{ha}^{-1}$ at five-leaf stage $=\mathrm{W} 2$ & $6.1^{\mathrm{b}}$ & $87^{\mathrm{b}}$ & $18^{\mathrm{b}}$ & $1.3^{\mathrm{b}}$ & $4.4^{\mathrm{b}}$ & $0.30^{\mathrm{a}}$ \\
\hline $2,4 \mathrm{D}$ at $0.75 \mathrm{~kg} \mathrm{ha}^{-1}$ at six-leaf stage $=\mathrm{W} 3$ & $5.3^{\mathrm{c}}$ & $82^{\mathrm{c}}$ & $15^{\mathrm{c}}$ & $1.0^{\mathrm{c}}$ & $4.0^{\mathrm{c}}$ & $0.25^{\mathrm{c}}$ \\
\hline $2,4 \mathrm{D}$ at $150 \mathrm{~kg} \mathrm{ha}^{-1}$ at five-leaf stage $=\mathrm{W} 4$ & $5.3^{\mathrm{c}}$ & $84^{\mathrm{c}}$ & $14^{\mathrm{cd}}$ & $1.1^{\mathrm{c}}$ & $3.9^{\mathrm{cd}}$ & $0.28^{\mathrm{b}}$ \\
\hline $2,4 \mathrm{D}$ at $150 \mathrm{~kg} \mathrm{ha}^{-1}$ at six-leaf stage $=\mathrm{W} 5$ & $4.6^{\mathrm{d}}$ & $78^{\mathrm{d}}$ & $12^{\mathrm{d}}$ & $1.0^{\mathrm{c}}$ & $3.6^{\mathrm{d}}$ & $0.28^{\mathrm{b}}$ \\
\hline \multicolumn{7}{|l|}{ Interaction } \\
\hline $\mathrm{T} \times \mathrm{F}$ & $*$ & $*$ & $* *$ & $* *$ & $* *$ & $*$ \\
\hline $\mathrm{T} \times \mathrm{W}$ & * & ns & * & * & * & $*$ \\
\hline $\mathrm{F} \times \mathrm{W}$ & ns & * & * & $* *$ & * & ns \\
\hline $\mathrm{T} \times \mathrm{F} \times \mathrm{W}$ & $* *$ & $* *$ & $* *$ & $* *$ & $* *$ & $*$ \\
\hline
\end{tabular}

Means within columns with different letters are significantly different at $P=0.05$.

${ }^{*}$ Significant at the 0.05 probability level; ${ }^{* *}$ significant at the 0.01 probability level; ns: nonsignificant at $P>0.05$.

$\times$ indicates interaction; TL: tiller number per plant counted just before harvesting; PH: plant height; PL: panicle length; GY: grain yield; AGB: above ground biomass yield; HI: harvest index.

T3 as the time for infiltration could be too short. In such conditions, crop can be exposed to moisture stress especially at establishment and grain-filling stages in which these affect the yield of the crop.

Among the fertilizer rates, F3 $\left(1.70 \mathrm{tha}^{-1}\right)$ followed by F4 (1.40 tha $\left.\mathrm{ha}^{-1}\right)$ showed a significantly higher mean grain yield. The greater response to $\mathrm{N}$ and $\mathrm{P}$ fertilizer was probably because of soil moisture improvement by tillage treatments such as T2, which was the major yield-limiting factor in dry areas. The $\mathrm{N}$ rate in $\mathrm{F} 3$ was within the recommended average rates of $\mathrm{N}\left(40-80 \mathrm{~kg} \mathrm{~N} \mathrm{ha}^{-1}\right)$ for tef crop [3,30]. From the weed control practices a higher mean grain yield was found using W1 (1.60 tha $\left.\mathrm{th}^{-1}\right)$ followed by W2 $\left(1.30 \mathrm{tha}^{-1}\right)$. The effect of the chemical weed control rates (broad leaf weeds) on grain yield of tef did show poor performance as compared to hand weeding (W1) (Table 4), but costbenefit analysis should be done to assess their feasibility. The reason for higher yield due to W1 could be associated with the fact that $\mathrm{W} 1$ is characterized by removing weeds from their root (uprooting) and this action can increase soil water infiltration. In addition, chemical weed control can harm the growth of the crop if chemicals are not applied on the appropriate growth stage of the crop. The effect of the treatments on HI showed a similar trend to that of biomass and grain yields, but pooled HI values were generally found to be very low. This could be attributed to the disproportionate in weights between grain yield and aboveground biomass yield which might be constrained by poor soil moisture and nutrients availability starting on the establishment and from the booting to grain filling stages of the crop.

\subsection{Implication of Treatment Effects as Compared to Previous} Studies. The study during 2008 crop season demonstrated that as tillage frequency increases, there is a possibility of increasing tef yield. This is consistent with the finding in Fufa et al. [31], who reported that increasing tillage frequency increased tef yield and increasing fertilizer level to certain point can increase yield and yield component of tef crop [3]. The report by Hati et al. [29] showed that frequent plowing controls weed growth which is the cause for about $35 \%$ of tef yield losses. The report in Rao et al. [32] also indicated that conventional tillage is superior to reduced tillage with crops such as barley (Hordeum vulgare) and chickpea (Cicer arietinum) grown under semiarid conditions in India.

In contrast to the above results, Aberra [33] reported that in the presence of proper weed management practices plowing more than once may not be necessary even for tef fields. In addition, frequent tillage incurs labor cost which is the critical problem of farmers who have no oxen and pay money for a farmer plowing their land [34]. In such situation, there should be a tillage system that reduces the effects of erosion and weed on soil nutrient and moisture 
availability of tef crop yield. Generally, soil infiltration, soil water holding capacity, and rainfall distribution and amount should be taken in account before deciding tillage frequency, because high tillage frequency can increase soil erosion which finally leads to yield reduction [35].

Studies by Aune et al. [20] and Kassie et al. [21] reported that reduced tillage increased crop productivity as compared to the traditional tillage system (about 6 times) and fertilized as compared to nonfertilized fields. These are consistent with the present finding in 2009 crop season but contradicted with the yield and yield components measured in 2008 crop season, indicating that reduced tillage improves the soil system (e.g., soil carbon sequestration, soil nutrients, and soil water holding capacity) and thereby crop productivity after some years as compared to traditional tillage $[20,36]$. Despite these facts, the short-term effect of four times tillage passes (T2) showed better yield and yield components of tef crop as compared to the other main treatments. This indicates that this is the optimum frequency of plowing in order to achieve the highest yield in the condition of the study site. In agreement to this result, the research in Mekelle (Ethiopia) by Habtegebrial et al. [3] showed a higher tef dry-matter, yield, and harvest index with four plowings using traditional plow when compared to minimum tillage even though there were not statistically different. However, their research did not evaluate the effect of more than four times tillage passes such as T1 which was included in the present study. Generally, four times tillage passes (T2) in the present study showed a higher ( $>60 \%$ increment) grain yield of tef as compared to the result reported by Habtegebrial et al. [3]. Such variability could be related to factors such as soil type, climate condition, cropping system, and crop and soil management practices.

Other researchers also reported that on some soils and under certain climatic conditions reduced tillage was found to be superior and more cost effective farming practice than conventional tillage $[34,35]$. In the literature, however, the economics of the tillage inputs and outputs is not considered, such as energy and labor costs as well as capital investment in equipment and the resultant effect on soils and production, both in the short- and long-term. Thus, research on tillage should address comprehensively the socioeconomic, physical, chemical, and biological effects.

Regardless of the importance of tillage as weed control practice, the application of herbicides by smallholder farmers is being increased from time to time to replace partly or wholly the dependence on hand weeding (manually) of weed control $[26,27]$. Because hand weeding is labor intensive and so is difficult to apply on time. Despite this, hand weeding can contribute to increase soil infiltration and not harm crop growth as in the case of chemicals. However, the intention of using chemicals by farmers is increasing from time to time even though there are some concerns such as dose and time of application on different crop types $[25,36]$. In this study, $2,4 \mathrm{D}$ at $0.75 \mathrm{~kg} \mathrm{ha}^{-1}$ at five-leaf stage (W2) performed better than the other herbicide treatments. This is consistent with the finding reported by Mersie and Parker [25] and Friesen and Olson [37]; that is, tef is tolerant to such herbicide rate at five-leaf stage. The report by Mersie and Parker [25] on the effect of 2,4D applied at the three- and four-leaf stages of tef showed leaf and stem deformities at both rates even though these authors did not determine grain yield reduction that resulted from such effects. The report by Friesen and Olson [37] also showed that 2,4D sprayed at the later stage of the crop may cause sterility. This study thus suggests that W2 seems to be optimum for tef crop weed control in the study area conditions.

\section{Conclusion}

This study demonstrated that the separate and interaction effects of tillage, fertilizer, and weed control treatments significantly affected the yield and yield components of tef crop. The four times tillage passes (T2) showed better yield and yield components as compared to the others. Similarly, the fertilizer rate of $23 \mathrm{~kg} \mathrm{Nha}^{-1}$ and $10 \mathrm{~kg} \mathrm{Pha}^{-1}$ (F3) and $23 \mathrm{~kg} \mathrm{~N} \mathrm{ha}^{-1}$ and $2.5 \mathrm{tha}^{-1}$ manure (F4) showed significantly higher yield of tef crop. Hand weeding (W1) resulted in a significantly better yield and yield component of tef crop as compared to the others. This suggests that there is a need for selecting herbicides that kill narrow leaf grasses to replace hand weeding and understanding of their effects across different growth stages, soil types, and climatic conditions. On the basis of this study it is suggested to demonstrate the promising treatments such as T2 and T3 with F3 and $\mathrm{F} 4$ at on-farm fields in order to evaluate their performance at farmers' conditions. In addition, cost-benefit analysis on the promising treatments should be conducted in order to disseminate to users the most viable techniques. In addition, it is suggested that the effect of reduced tillage (T3) on medium and long-term period should be evaluated on tef yield and yield components and soil properties dynamics in the condition of Cambisols.

\section{Conflict of Interests}

The author declares that there is no conflict of interests regarding the publication of this paper.

\section{Acknowledgments}

This research was conducted with the financial support provided by the University of Nebraska, USA, to Aksum University under the prime award or terms of Grant no. EEP-A-00-06-00016-00 by the U.S. Agency for International Development (USAID) for the Project entitled "Sorghum, Millet, and Other Grains Collaborative Research Support Program" also referred to as INTSORMIL. The author gratefully acknowledges Mekonen Aregai, Chigign Adamu, and Ashenafi Gebrelibanos for their support during data collection and field monitoring of the research.

\section{References}

[1] S. Ketema, "Phenotypic variations in Tef (Eragrostis tef) germplasm-morphological and agronomic traits," A Catalon Technical Manual 6, Institute of Agricultural Research, Addis Ababa, Ethiopia, 1993. 
[2] Central Statistical Authority, Agricultural Sample Survey, 2009/2010 Area and Production for Major Crops in Private Peasant Holdings, CSA, Addis Ababa, Ethiopia, 2011.

[3] K. Habtegebrial, B. R. Singh, and M. Haile, "Impact of tillage and nitrogen fertilization on yield, nitrogen use efficiency of tef (Eragrostis tef (Zucc.) Trotter) and soil properties," Soil and Tillage Research, vol. 94, no. 1, pp. 55-63, 2007.

[4] F. Kebede and C. Yamoah, "Soil fertility status and Numass fertilizer recommendation of Typic Hapluusterts in the Northern Highlands of Ethiopia," World Applied Sciences Journal, vol. 6, pp. 1473-1480, 2009.

[5] T. Oicha, W. M. Cornelis, H. Verplancke et al., "Short-term effects of conservation tillage on soil (Vertisol) and crop (teff, Eragrostis tef) attributes in the orthern Ethiopian highlands," in Proceedings of the 19th World Congress of Soil Science, Soil Solutions for a Changing World, pp. 149-152, Brisbane, Australia, August 2010.

[6] W. Mersie and C. Parker, "Response of teff (Eragrostis tef (Zucc.) Trotter) to 2,4-D and MCPA at various growth stages," Weed Research, vol. 23, no. 1, pp. 53-59, 1983.

[7] L. R. Oldeman, R. T. A. Hakkeling, and W. G. Sombroek, "World map of the status of human-induced soil degradation," An Explanatory Note, ISRIC, Wageningen, DC, USA, 1991.

[8] S. Gebregziabher, A. M. Mouazen, H. Van Brussel et al., "Animal drawn tillage, the Ethiopian ard plough, maresha: a review," Soil and Tillage Research, vol. 89, no. 2, pp. 129-143, 2006.

[9] J. J. Stoorvogel and E. M. A. Smaling, "Assessment of soil nutrient depletion in sub-saharan Africa," Report 28, DLO Winand Staring Center for Integrated Land, Soil and Water Research, Wageningen, The Netherlands, 1990.

[10] K. C. Kaizzi, J. Byalebeka, C. S. Wortmann, and M. Mamo, "Low input approaches for soil fertility management in semiarid eastern Uganda," Agronomy Journal, vol. 99, no. 3, pp. 847-853, 2007.

[11] J. Iqbal, J. A. Thomasson, J. N. Jenkins, P. R. Owens, and F. D. Whisler, "Spatial variability analysis of soil physical properties of alluvial soils," Soil Science Society of America Journal, vol. 69, no. 4, pp. 1338-1350, 2005.

[12] S. Zhang, X. Zhang, T. Huffman, X. Liu, and J. Yang, "Influence of topography and land management on soil nutrients variability in Northeast China," Nutrient Cycling in Agroecosystems, vol. 89, no. 3, pp. 427-438, 2011.

[13] R. L. Hill, "Long-term conventional and no-tillage effects on selected soil physical properties," Soil Science Society of America Journal, vol. 54, no. 1, pp. 161-166, 1990.

[14] D. E. Buschiazzo, J. L. Panigatti, and P. W. Unger, "Tillage effects on soil properties and crop production in the subhumid and semiarid Argentinean Pampas," Soil and Tillage Research, vol. 49, no. 1-2, pp. 105-116, 1998.

[15] T. Tsegaye and R. L. Hill, "Intensive tillage effects on spatial variability of soil physical properties," Soil Science, vol. 163, no. 2, pp. 143-154, 1998.

[16] J. A. Gómez, J. V. Giráldez, M. Pastor, and E. Fereres, "Effects of tillage method on soil physical properties, infiltration and yield in an olive orchard," Soil and Tillage Research, vol. 52, no. 3-4, pp. 167-175, 1999.

[17] E. Özgöz, F. Akb, M. Çetin, S. Ersahin, and H. Günal, "Spatial variability of soil physical properties as affected by different tillage systems," New Zealand Journal of Crop and Horticultural Science, vol. 35, no. 1, pp. 1-13, 2007.
[18] T. Araya, W. M. Cornelis, J. Nyssen et al., "Effects of conservation agriculture on runoff, soil loss and crop yield under rainfed conditions in Tigray, Northern Ethiopia," Soil Use and Management, vol. 27, no. 3, pp. 404-414, 2011.

[19] T. Araya, W. M. Cornelis, J. Nyssen et al., "Medium-term effects of conservation agriculture based cropping systems for sustainable soil and water management and crop productivity in the Ethiopian highlands," Field Crops Research, vol. 132, pp. 53-62, 2012.

[20] J. B. Aune, R. Asrat, D. A. Teklehaimanot, and B. T. Bune, "Zero tillage or reduced tillage: the key to intensification of the crop-livestock system in Ethiopia," Chapter 12, 2006, http://www.ifpri.org/sites/default/files/pubs/pubs/books/oc53 /oc53ch12.pdf.

[21] M. Kassie, J. Pender M Yesuf, G. Köhlin, R. Bluffstone, P. Zikhali, and E. Mulugeta, Sustainable Land Management Practices Improve Agricultural Productivity: Evidence on Using Reduced Tillage, Stone Bunds, and Chemical Fertilizer in the Ethiopian Highlands, Environmental for Development, EFD Policy Brief, Stockholm, Sweden, 2008.

[22] A. Rachman, S. H. Anderson, C. J. Gantzer, and A. L. Thompson, "Influence of long-term cropping systems on soil physical properties related to soil erodibility," Soil Science Society of America Journal, vol. 67, no. 2, pp. 637-644, 2003.

[23] L. N. Mulumba and R. Lal, "Mulching effects on selected soil physical properties," Soil and Tillage Research, vol. 98, no. 1, pp. 106-111, 2008.

[24] J. D. Jabro, W. B. Stevens, R. G. Evans, and W. M. Iversen, "Tillage effects on physical properties in two soils of the Northern Great Plains," Applied Engineering in Agriculture, vol. 25, no. 3, pp. 377-382, 2009.

[25] W. Mersie and C. Parker, "Response of teff (Eragrostis tef (Zucc.) Trotter) to 2,4-D and MCPA at various growth stages," Weed Research, vol. 23, no. 1, pp. 53-59, 1983.

[26] B. Haile, "Report on surveys and experiments carried out in 1972," CADU Publication 87, 1973.

[27] D. R. Tottman, “The identification of growth stages in winter wheat with reference to the application of growth regulatory herbicides," Annals of Applied Biology, vol. 87, pp. 213-224, 1977.

[28] F. A. O./UNSCO, Soil Map of the World, UNSCO, Paris, France, 1984.

[29] K. M. Hati, K. G. Mandal, A. K. Misra, P. K. Ghosh, and K. K. Bandyopadhyay, "Effect of inorganic fertilizer and farmyard manure on soil physical properties, root distribution, and water-use efficiency of soybean in Vertisols of central India," Bioresource Technology, vol. 97, no. 16, pp. 2182-2188, 2006.

[30] National Fertilizer and Inputs Unit, "Agronomic feasibility of the proposed recommendations and comparison with the previous recommendations," General Paper 17, NFIU, Addis Ababa, Ethiopia, 1993.

[31] H. Fufa, B. Tesfa, T. Hailu et al., "Agronomy research in tef," in Proceeding of the International Workshop on Tef Genetics and Improvement, T. Hailu, B. Getachew, and S. Mark, Eds., Narrowing the Rift: Tef Research and Development, pp. 167-173, Debrezeit, Ethiopia, October 2001.

[32] P. Rao, S. K. Agrawal, and O. P. Bishnoc, "Yield variations in winter crops under different soil tillage and moisture conservation practices," Indian Journal of Ecology, vol. 13, pp. 244-249, 1986.

[33] D. Aberra, Germination, yield and yield components of tef (Eragrostis tef (Zucc.) Trotter) as affected by environment, 
tillage and weed control practices [Ph.D. thesis], Oklahoma State University, Stillwater, Okla, USA, 1992.

[34] J. B. Aune, M. T. Bussa, F. G. Asfaw, and A. A. Ayele, "The ox ploughing system in Ethiopia: can it be sustained?" Outlook on Agriculture, vol. 30, no. 4, pp. 275-280, 2001.

[35] H. Kruger, F. Berhanu, G. Yohannes, and K. Kefeni, "Creating an inventoty of indigenous soil and water conservation measures in Ethiopia," in SustaInIng the Soil Indigenous Soil and Water Conservation in Africa, R. Chris, S. Ian, and T. Camilla, Eds., International Institute for Environment and Development, London, UK, 1996.

[36] R. L. Desjardins, W. Smith, B. Grant, C. Campbell, H. Janzen, and R. Riznek, "Management strategies to sequester carbon in agricultural soils and to mitigate greenhouse gas emissions," in Proceedings of the International Workshop on Reducing Vulnerability of Agriculture and Forestry to Climate Variability and Climate Change, Ljubljanu, Slovenia, October 2002.

[37] G. Friesen and P. J. Olson, "The effect of 2,4-D on the developmental processes in barley and oats," in Canadian Journal of Agricultural Science, vol. 33, pp. 315-329, 1953. 


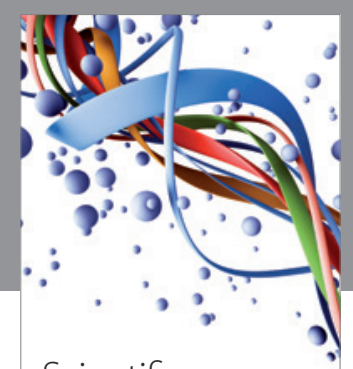

Scientifica
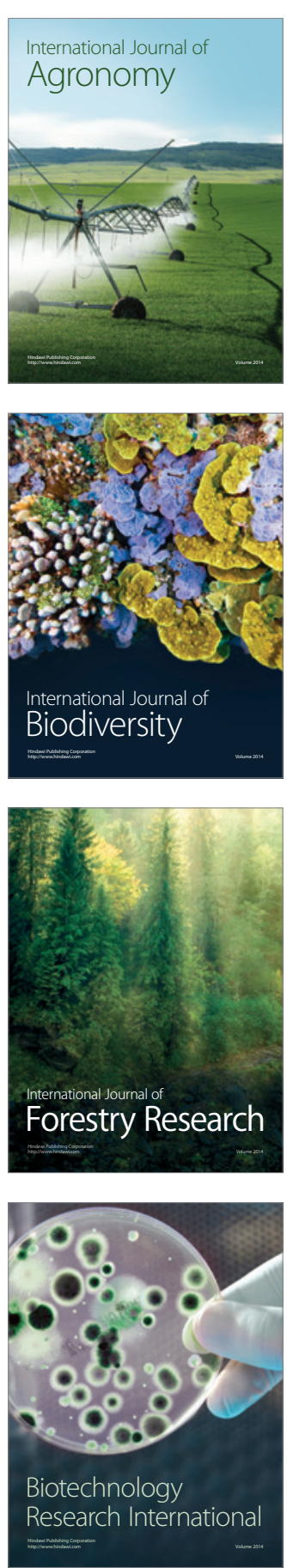
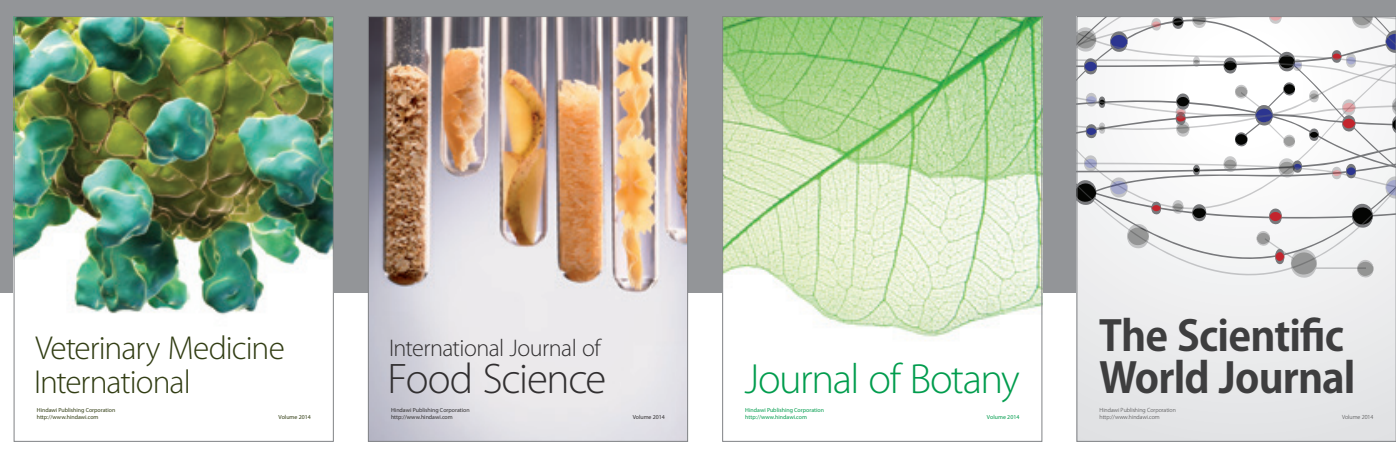

The Scientific World Journal
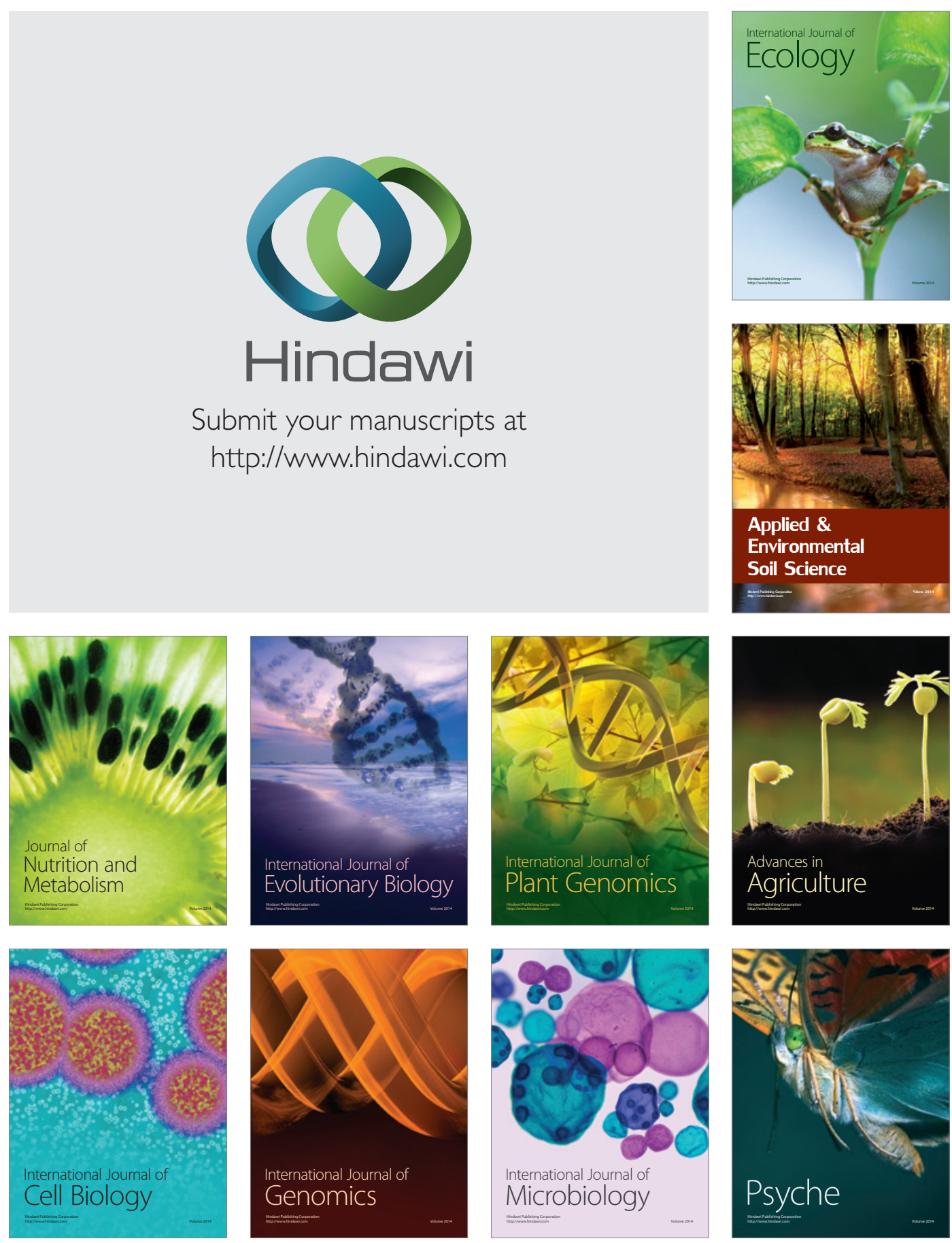